\title{
Struggling Over Healthy Lifestyles
}

\section{The Dutch Nutrition Education Bureau and the Individualisation of Public Health (1940-1980)}

JON VERRIET

In the second half of the twentieth century, advice on healthy living became pervasive in Western societies. While scholars have shown how the output of health educators echoed scientific consensus and ideas about 'good citizenship', the impact of their interactions with government and food industry representatives, and especially their complicated relationship with audiences, remains underexplored. This article centres the experiences of the staff of the Dutch Nutrition Education Bureau - now known as the Centre for Nutrition (Voedingscentrum) - by examining health educators' own observations about the efficacy of their work. Using sources such as internal guidelines, surveys, minutes of meetings, and annual reports, it demonstrates how the bureau struggled to position itself towards government ministries and commercial parties. Furthermore, it shows how unsuccessful attempts to reach the general population frustrated educators, and proposes that these struggles partially explain the transformation of the bureau's lifestyle advice in the 1970s into a 'healthist' narrative about the responsibility of individuals. Hence, by analysing the complex interactions between health educators and other actors - in particular their audience - this article sheds light on the historical development of the genre of lifestyle advice.

Tips over 'gezond leven' werden in de tweede helft van de twintigste eeuw onontkoombaar in veel Westerse samenlevingen. Studies hebben aangetoond dat gezondheidsvoorlichters zich in deze periode lieten leiden door de wetenschappelijke consensus en ideeën over 'deugdelijk burgerschap'. Er is echter minder wetenschappelijke aandacht geweest voor de impact van interacties tussen voorlichters, overheid en voedselindustrie, of voor de gecompliceerde relatie die gezondheidsvoorlichters onderhielden met hun publiek. Dit artikel focust op de 
ervaringen van het personeel van het Nederlandse Voorlichtingsbureau voor de Voeding - nu bekend als het Voedingscentrum - en onderzoekt hun eigen ideeën over de effectiviteit van hun promotiemateriaal. Aan de hand van bronnen als vergaderverslagen, interne richtlijnen, peilingen, en jaarverslagen, toont het aan dat het bureau twijfelde over zijn positionering richting de ministeries en commerciële partijen. Bovendien laat het zien hoe onsuccesvolle pogingen het publiek te bereiken leidden tot frustratie bij de voorlichters, en stelt het dat deze worstelingen deels verklaren waarom het bureau in de jaren zeventig gezondheid in toenemende mate presenteerde als de individuele verantwoordelijkheid van burgers zelf. Door de complexe interacties tussen gezondheidsvoorlichters en andere partijen - met name het eigen publiek - te bestuderen, biedt dit artikel inzicht in de historische ontwikkeling van het leefstijladvies-genre.

\section{Introduction}

In the second half of the twentieth century, advice on healthy living became pervasive in Western societies. Convinced that people's rising body weight and sedentary lifestyles were detrimental to their well-being, health educators disseminated guidelines on dietary choices and physical exercise. ${ }^{2}$ In the Netherlands and in other countries, these instructions increasingly treated people as independent consumers whose individual lifestyle choices shaped public health. This way of thinking, termed 'healthism' by political economist Robert Crawford, moralised personal health as one of the duties of a 'responsible citizen'. ${ }^{3}$ While this way of thinking was not new ${ }^{4}$,

This research project is funded by the Radboud Institute for Culture \& History and embedded in the Sport History research group at Radboud University Nijmegen. The author would like to thank Marjet Derks, Edith Feskens, Jan Hein Furnée, Bram Mellink, Peter Scholliers and members of the cultural and political history sections at Radboud University for their feedback during the research process and the reviewers for their helpful comments on an earlier version of the article.

Ulrike Thoms, 'Learning from America? The travels of German nutritional scientists to the USA in the context of the Technical Assistance Program of the Mutual Security Agency and its consequences for the West German Nutritional Policy', Food \& History 2:2 (2004) 117-152, 147-148. DOI: https://doi. org/10.1484/J.FOOD.2.300100; Mark W. Bufton, 'British Expert Advice on Diet and Heart Disease, c. 1945-200o', in: Virginia Berridge (ed.), Making Health Policy: Networks in Research and Policy after 1945. Clio Medica 75 (Amsterdam/Atlanta 2005) 125-148, 131; Marion Nestle, Food Politics: How the Food Industry Influences Nutrition and Health (Berkeley 2007) 38-50.

3 Robert Crawford, 'Healthism and the Medicalization of Everyday Life', International Journal of Health Services 10:3 (1980) 365-388. DOI: https://doi.org/10.2190/3H2H-3XJN-3KAY-G9NY; Petr Skrabanek, The Death of Humane Medicine and the Rise of Coercive Healthism (London 1994) 17. Helen Zoe Veit, Modern Food, Moral Food: SelfControl, Science, and the Rise of Modern American Eating in the Early Twentieth Century (Chapel Hill 2013) 19; Christianne Smit, De volksverheffers. Sociaal hervormers in Nederland en de wereld, 1870-1914 (Hilversum 2015) 253-337. 
in the mid-1970s the belief gained significant ground that people would be able to regulate their own health through disciplined and healthy lifestyle choices. ${ }^{5}$ In critical nutrition studies and fat studies, scholars have identified the problematic effects of such narratives ${ }^{6}$, arguing that the advice given by health educators constituted a form of biopolitics. ${ }^{7}$ According to these critical perspectives, a significant consequence of the pronounced 'healthist' discourse of the 1970 s was the further stigmatisation of the body weight of individuals, which intersected with existing sexist, racist, and classist ideas. ${ }^{8}$

However, this focus on the healthist implications of lifestyle advice limits our understanding of health educators as historical actors themselves. Because scholars of critical nutrition studies and fat studies often present their instructions as the logical product of ideas about 'good citizenship' and scientific consensus, health educators are treated as a somewhat isolated group, with a significant amount of agency. While some research examines the interactions between health educators and representatives of government and the food industry ${ }^{9}$, it is particularly the complex relationship between these lifestyle educators and the general population - their principal target audience - that remains underexplored. Therefore, this article centres the experiences of health educators themselves to examine if and how their perceptions of (their relationship with) government officials, the food industry, and especially their target audience shaped their instructions. By investigating educators' own observations about the reception of their work, this article aims to facilitate a deeper understanding of the genre of lifestyle advice, and the developments that led to the start of its transformation in the 1970 .

on the Premises and Outcomes of European

Anti-“Obesity-Epidemic” Policies', Fat Studies: An Interdisciplinary Journal of Body Weight and Society 2:1 (2013) 3-16, 8. DOI: https://doi.org/10.1080/21604851.20 12.654722; Klasien Horstman, 'Struggling with Science and Democracy: Public Health and Citizenship in the Netherlands', in: Frank Huisman and Harry Oosterhuis (eds.), Health and Citizenship: Political Cultures of Health in Modern Europe (London 2014) 191-208, 192.

6 For example: Charlotte Biltekoff, Eating Right in America: The Cultural Politics of Food and Health (Durham/London 2013); Adele H. Hite, 'Nutritional Epidemiology of Chronic Disease and Defining “Healthy Diet"', Global Food History 4:2 (2018) 207-225. DOI: https://doi.org/10.1080/20549547.20 18.1498256; Alexandra Brewis and Amber Wutich, Lazy, Crazy, and Disgusting: Stigma and the Undoing of Global Health (Baltimore 2019) 102-104.
7 Christopher R. Mayes and Donald B. Thompson, 'What Should We Eat? Biopolitics, Ethics, and Nutritional Scientism', Journal of Bioethical Enquiry 12:4 (2015) 587-599, 588. DOI: https://doi.org/ 10.1007/s11673-015-9670-4. Mayes and Thompson cite Michel Foucault's Security, Territory, Population: Lectures at the Collège de France 1977-1978 (New York 2007).

Melanie DuPuis, 'Angels and Vegetables: A Brief History of Food Advice in America', Gastronomica 7:3 (2007) 34-44, 39-41. DOI: https://doi.org/10.1525/ gfc.2007.7.3.34; Natalie Boero, Killer Fat: Media, Medicine and Morals in the American "Obesity Epidemic" (New Brunswick 2011) 52-55; Hite, 'Nutritional Epidemiology', 212, 218.

9 For example: Nestle, Food Politics; Gyorgy Scrinis, Nutritionism: The Science and Politics of Dietary Advice (New York 2013); Biltekoff, Eating Right. 
To analyse lifestyle educators' changing perception of their target audience in the post-war era, I focus on the Dutch Nutrition Education Bureau (Voorlichtingsbureau voor de Voeding, now known as the Centre for Nutrition, or Voedingscentrum). The archives of this bureau allow for an analysis of detailed material on the attitudes and reflections of nutrition educators, which is rare in both the Dutch and the international literature. ${ }^{10}$ Founded in 1941 and nominally an independent foundation from 1956 onwards, the bureau was set up and principally funded by the Dutch government to encourage healthy eating habits among the general population. ${ }^{11}$ In reality, its ambitions went far beyond diet, as it tried to improve public health by promoting broad lifestyle changes. There is good reason for focusing on the Netherlands, since the country played a pioneering role in the history of European nutrition education. Not only did several Dutch nutrition experts join the Mixed Committee on the Problem of Nutrition of the League of Nations (1935-1937) and the FAO/WHO Joint Expert Committee on Nutrition (1948 to date), but the Dutch Nutrition Education Bureau itself also aspired to be a global leader in education methods and material. ${ }^{12}$ From an international perspective, the bureau's high ambitions, broad scope and comparatively early start make it a compelling target for studying the changing attitude of lifestyle educators to their audience.

The source material used for this article can be divided into three categories. First, I examined minutes of board meetings and advisory board meetings, and internal guidelines and surveys. These allow for a look 'behind the scenes'. Both boards discussed, among other things, new methods in education and ways to maintain an (inter)national network. The second category of sources consists of communications from the bureau to external health professionals: its yearly reports, and a selection of articles published by bureau staff in Voeding (the Netherlands Journal of Nutrition, 1939-1998). ${ }^{13}$ Hartog's overview of the bureau's wartime efforts: Adel P. den Hartog, 'Nutrition Education in Times of Food Shortages and Hunger: War and Occupation in the Netherlands, 1939-1945', in: Ina ZweinigerBargielowska, Rachel Duffett and Alain Drouard (eds.), Food and War in Twentieth Century Europe (Farnham 2011) 183-198. DOI: https://doi.org/ $10.4324 / 9781315582641$.

Its original name, 'Voorlichtingsbureau van den Voedingsraad', was changed in 1956. National Archive, Stichting Voorlichtingsbureau voor de Voeding, 2.11.96, inventory number (hereafter 'NA, 2.11.96, inv.') 15: Board meeting of 3 November 1965.

In this article, the 'bureau' itself features as an anonymous - source material. NA, 2.11.96, inv. 18: Verslag van een dienstreis naar Londen. cooperation'. 'Verslag van de werkzaamheden van het voorlichtingsbureau van den voedingsraad gedurende het dienstjaar 1945' (hereafter 'Yearly DNEB Report 1945'), Verslagen en Mededelingen betreffende de Volksgezondheid (hereafter VMBV) (1946) $23-40,24$. Any original article involving a meta perspective on the methods and purposes of nutrition education, plus any article about sport and physical exercise, was selected for this research (83 articles, 1941-1980). In 1998, the journal merged with another publication, and its name was changed to Voeding Nu. actor. This is the product of the - mostly 
The former contain statistics on material that was published by the bureau, and reported on contacts made with Dutch health professionals, foreign experts and their audience. In addition to being published in Voeding, the yearly reports were sent to ministers, schools for home economics, and consumer and women's organisations. The third type of source comprises promotional material geared directly towards the general population: press releases, leaflets and two films. As this article focuses on the changing attitude of the bureau towards its target audience, the first two categories of sources are most pertinent to its narrative. This focus also means that sources pertaining the bureau's long-term goals were of more interest to this research than those aimed at passing pursuits of the bureau, such as brochures on growing beets or pamphlets about hygiene in industrial kitchens.

The article roughly spans the period of 1940 to 1980 . This periodisation is crucial, as insight into the period of 1940-1970 helps to understand health educators' evolving perception of their target audience, and more specifically their changing approach in the 1970s. The first two sections explain the bureau staff's perception of the parameters within which they worked. The first section contextualises the foundation of the bureau and sketches its initial post-war ambitions. The second provides a short analysis of how the bureau conceived its evolving relationships with two actors, the Dutch government ministries and the food industry. Then, the article's last three sections examine the bureau's work within the perceived parameters, zooming in on its complex relationship with its target audience. They show how the bureau conceptualised and addressed the Dutch population, and how the reflexive approach and the constantly evolving methods of educators could not prevent their increasing frustrations in trying to reach and influence their audience. The article ends with the second half of the 1970s, when the disillusionment of bureau staff led, in part, to a lasting change in the way nutrition educators approached the population.

\section{The foundation and the ambitions of the Dutch Nutrition Education Bureau}

In many European countries, the period between the two world wars was one of rising governmental concern about nutrition. ${ }^{14}$ The growing number of malnourished individuals - a consequence of the Great Depression - showed an increasing need for a comprehensive approach to food policy. This, along with the discovery of vitamins, gave a clear impulse to nutrition education. ${ }^{15}$

15 Kenneth J. Carpenter, 'A Short History of Nutritional Science: Part 3 (1912-1944)', Journal of Nutrition 133:10 (2003) 3023-3032. DOI: https://doi.org/10.1093/ jn/133.10.3023. 
Paradoxically, the economic crisis restrained government funding. Therefore, European initiatives for governmental nutrition education remained few, even by the end of the 1930s. In countries such as the uK and the Netherlands, nutrition science and education were underfunded before the Second World War, and the Dutch government agencies concerned with nutrition, such as the Health Council, saw several budget cuts. ${ }^{16}$ Home economists in the Netherlands did receive subsidies for nutrition education in the 1930s, but they targeted specific subgroups of the population, such as the unemployed. ${ }^{17}$ This is why, as late as 1937, the League of Nations called on national governments to devise a comprehensive food policy. ${ }^{18}$

This appeal was picked up by a small group of Dutch officials. Cornelis van den Berg, Director-General of Public Health, felt that the Dutch Health Council was not equipped to treat food issues with the seriousness they deserved and strove to establish a council centred on nutrition. ${ }^{19}$ Talks about creating a Nutrition Council had been underway prior to the Second World War, but after the German invasion in May 1940, Leendert Kersbergen - the director of the Health Council - acted swiftly. Just twelve days after the invasion, the new Nutrition Council held its first meeting. ${ }^{20}$ Originally, nutrition education was to be the task of a subcommittee of the Nutrition Council, but by the autumn of 1940 it had become evident that this sizeable undertaking demanded the establishment of a separate bureau. ${ }^{21}$ In 1941 , the Dutch Nutrition Education Bureau was founded, its official name being the Education Bureau of the Nutrition Council (Voorlichtingsbureau van den Voedingsraad). It was subsidised by the State Bureau for the Food Supply in Times of War (Rijksbureau voor de Voedselvoorziening in Oorlogstijd) and housed in The Hague, in the same building as the Health Council and the Nutrition Council.

In a relatively short time, a small group of government officials had created an infrastructure for Dutch nutrition policies. These initiators World Wars', in: David F. Smith (ed.), Nutrition in Britain: Science, Scientists and Politics in the Twentieth Century (London/New York 1997) 142-165, 150, 154. DOI: https://doi.org/10.4324/9781315003979; René Rigter, Met raad en daad. De geschiedenis van de Gezondheidsraad 1902-1985 (PhD thesis; Erasmus University Rotterdam 1992) 74-76. De belofte van vitamines: Voedingsonderzoek tussen universiteit, industrie en overheid 1918-1945 (Hilversum 2011) 117. Policy', Nutrition Reviews 55:11 (1997) S1-S3, S1.
DOI: https://doi.org/10.1111/j.1753-4887.1997. tbo1569.x.

Cornelis van den Berg, 'Over het ontstaan van de Voedingsorganisatie T.N.O. en van de Voedingsraad en over het werk van deze laatste gedurende de bezetting', Voeding 26:6 (1965) 299-309, 299.

Mulder, 25 jaar Voedingsraad in Nederland', Voeding 26:6 (1965) 310-318, 310; Cornelis den Hartog, 'Tien jaren Voedingsraad', Voeding 11:6 (1950) 199-216, 199. Cornelis den Hartog, 'Voedingsvoorlichting in Nederland', Voeding 21:9 (1960) 459-463, 459; Huijnen, De belofte, 132. 


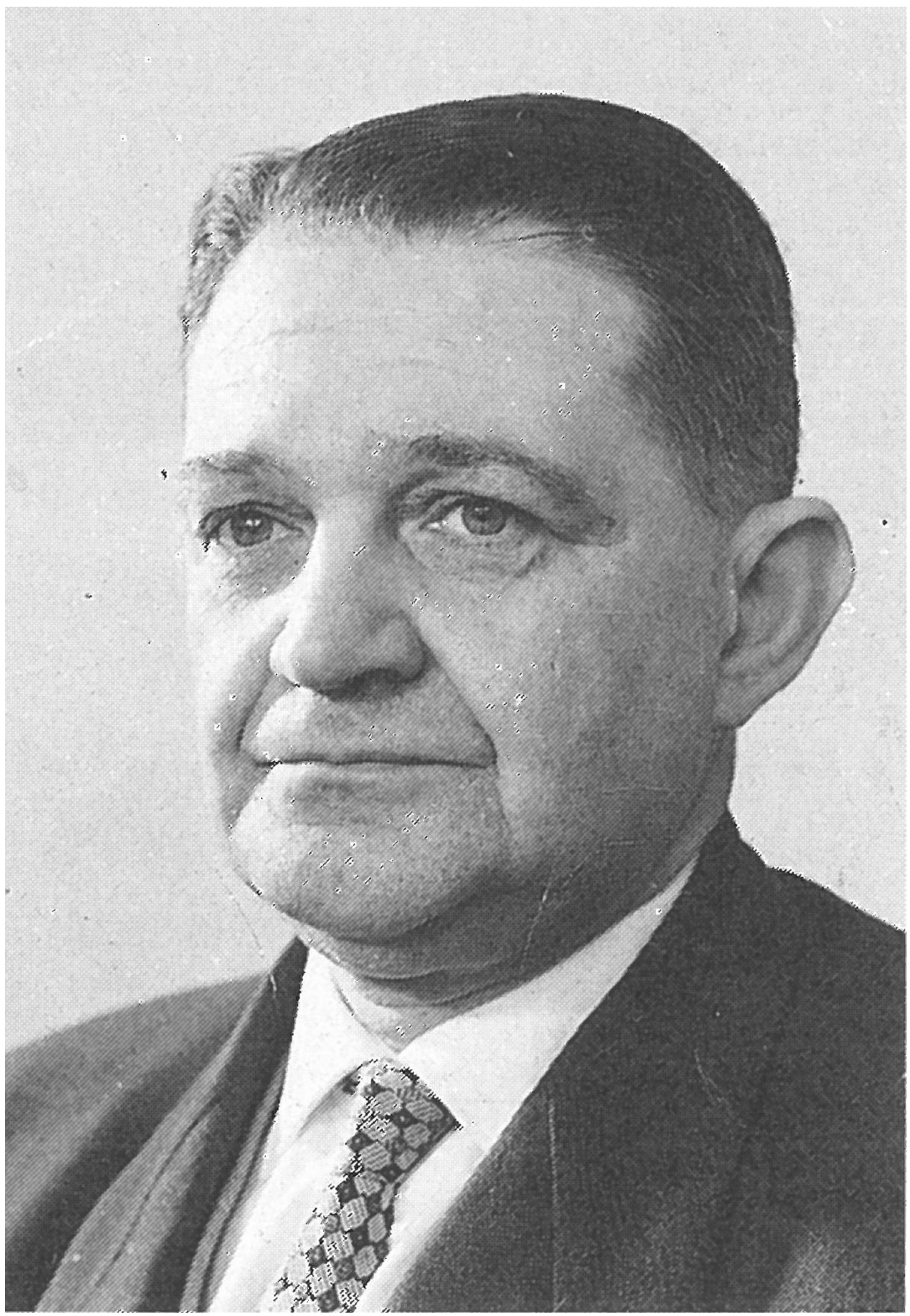

$\Delta$

Figure 1. Cornelis den Hartog (1905-1993), the strong-willed director of the Dutch Nutrition Education Bureau from its foundation in 1941 until 1969. (C) Voedingscentrum.nl. 
often took on roles as nutrition scientists and educators that blurred the lines between academia and the government. ${ }^{22}$ One notable example is the prolific Matthieu J.L. Dols (1902-1980), who was intricately involved in the foundation of the Dutch Nutrition Education Bureau. After the Second World War, he would go on to become director of the Nutrition Council and chairman of the bureau's board. However, he also remained active in nutrition research as an endowed professor in Nutrition and Food Supply at the University of Amsterdam and as a board member of the journal Voeding. ${ }^{23}$ Though few nutrition scientists or educators had careers as notable as that of Dols, many staff members of the bureau contributed to scientific discourse and served on committees.

During the war, however, the bureau's main aim was to distribute information 'to every Dutch person' on how to compose healthy meals despite food rationing and scarcity. ${ }^{24}$ Its fifteen educators - all women - worked with other agencies to provide leaflets, films, lectures and cookery lessons for housewives. ${ }^{25}$ Director Cornelis den Hartog (1905-1993) (Figure 1) travelled the country, disseminating the bureau's messages about cooking economically and the importance of vitamins. This young physician would turn out to become a very influential figure in both nutrition science and nutrition education, not just as the bureau's director from 1941 to 1969, but also as a professor in Human Nutrition at the National Agricultural University of Wageningen (from 1954 to 1972). Known for his - at times stubborn - dedication, Den Hartog would go on to produce over two hundred publications. ${ }^{26}$

After the Second World War, the continued existence of the bureau was far from certain. As most food rationing had been lifted by the end of the 1940 and the affluence of the Dutch population rose, malnutrition seemed a problem of the past. ${ }^{27}$ In 1947, the Dutch government slashed the bureau's budget by no less than 40 per cent. ${ }^{28}$ As the Netherlands became a society of consumers, a new justification for nutrition education was needed.

Consequently, the bureau's focus shifted towards prosperity-related issues: dental caries and, more importantly, 'overeating'. By 1949, an internal document as well as the annual report mentioned the disadvantages of eating 330. For more on the bureau's war years, see: Den Hartog, 'Nutrition Education'.

'Yearly DNEB Report 1941', vMBV (1942) 637-683, 655.

Theodora van Schaik, 'Professor Dr. C. den Hartog
Voeding 31:11 (1970) 540-546; Willem Bosman, 'In memoriam prof. dr. C. den Hartog', Voeding 54:4 (1993) 4-5, 5 .

27 the Netherlands, 1950-1970', Food \& History 11:1 (2013) 123-153, 127-131. DOI: https://doi.org/10.1484/J. FOOD.1.103558.

28 NA, 2.11.96, inv. 28: Advisory Board meeting of 16 December 1946. en het Voorlichtingsbureau voor de Voeding', 


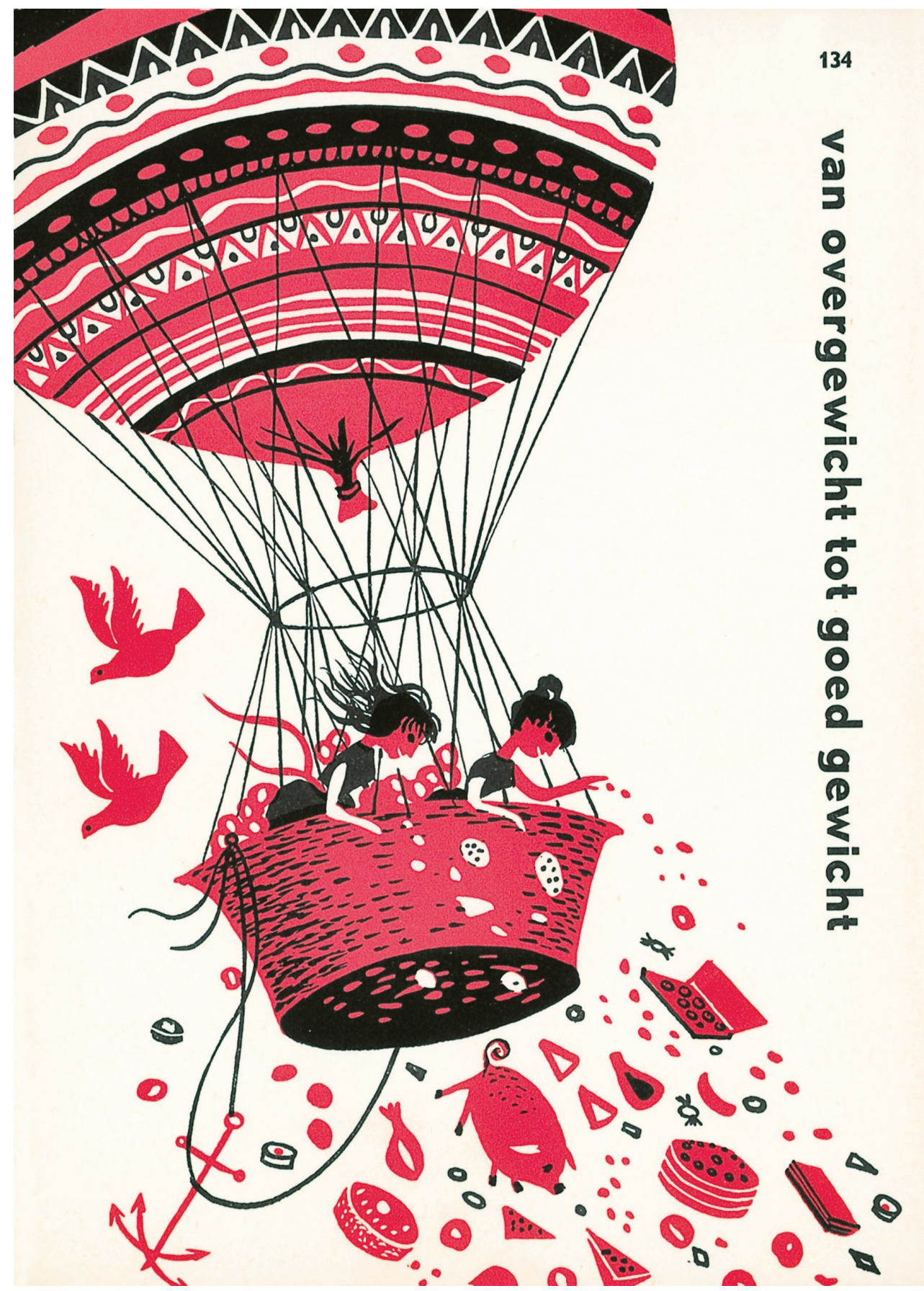

$\Delta$

Figure 2. The cover of From overweight to good weight (Van overgewicht naar goed gewicht), The Hague 1958.

(C) https://www.voedingscentrum.nl/. Illustration by Jenny Dalenoord. 
to excess, and 1952 saw the bureau's first press release on body weight, titled A slim figure (De slanke lijn). ${ }^{29}$ At the same time, per capita consumption of sugar and fats - seen as an important threat to public health - doubled in the Netherlands between 1947 and $1957 \cdot{ }^{30}$ Accordingly, by the end of the 1950s, overeating had become the bureau's core issue. ${ }^{31}$ The year 1958 saw the publication of From overweight to good weight (Van overgewicht naar goed gewicht, see Figure 2), an eight-page leaflet that generated 'great interest' ${ }^{32}$ It stressed the relationship between body weight and health, claiming that 'extra pounds place an extra burden on our heart', but ended on a positive note:

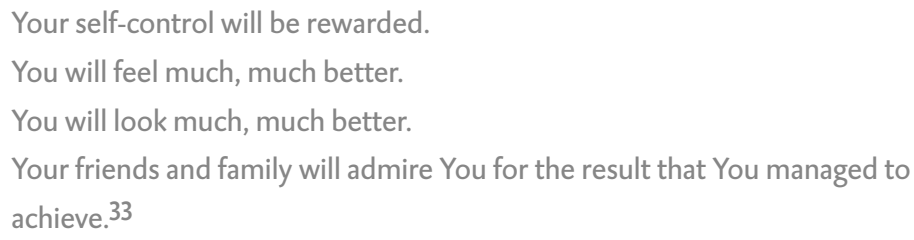

The Dutch Nutrition Education Bureau's change in orientation in the 1950 s was part of an international re-evaluation of (Western) food habits. A key moment came in 1951, when the FAO/WHo Expert Committee on Nutrition zoomed in on the intake of carbohydrates and fats, and called overconsumption 'a problem of major significance'. ${ }^{34}$ Though government warnings against 'disproportionate' sugar and fat consumption were not new in the United States, the first serious analyses of the effects of excessive eating took place in the $1950{ }^{35}$ All over Europe and in the us, scientists saw what Germans called a Fresswelle (feeding spree), and by the 1960 obesity had become the number one issue in nutrition journals. ${ }^{36}$ In little more than ten years, the message of nutrition educators had reversed completely: from 'eat more' to 'eat less'. The fate of nutrition science had briefly been uncertain, en taakvoorgangers en de Stuurgroep Project Goede Voeding (1987-1998) 2.11.88 (hereafter: '2.11.88'), inv. 38: Press releases 1947-1956; NA, 2.11.88, inv. 279: Leidraad voor voorlichtingscursussen...; 'Yearly DNEB Report 1949', VMBV (1950) 313-344, 313. voeding (Zutphen 2003) 262-279, 275.

'Yearly DNEB Report 1959', VMBV (1960) 1167-1211, 1169.

'Yearly DNEB Report 1958', VMBV (1959) 1227-1267, 1233. zult $U$ veel en veel prettiger voelen. $U$ zult er veel en veel beter uitzien. Uw vrienden en familie zullen $U$ bewonderen om het resultaat, dat $U$ hebt weten te bereiken'. Translation by author. NA, 2.11.96, inv. 12: 'Van overgewicht naar goed gewicht'.

34 Joint FAO/WHO Expert Committee on Nutrition, Report on the Second Session (Rome 1951) 43.
Helsing, 'The History', S1.

Jessica Mudry, 'Nutrition, Health, and Food:

“What should I eat?", in: Kathleen LeBesco and Peter Naccarato (eds.), The Bloomsbury Handbook of Food and Popular Culture (London/ New York 2018) 274-285, 280. DOI: https://doi. org/10.5040/9781474296250.0029. 
but was now 'rescued by obesity', as one prominent nutritionist later put it. ${ }^{37}$ As overeating grew into what many considered an important societal problem, the relevance of nutrition education increasingly seemed indisputable.

In taking on the issue of overeating, the Dutch Nutrition Education Bureau set itself a formidable task, although such great ambitions were typical for the organisation. In 1946, it had already expressed the desire to make "every Dutch person "food-minded"". ${ }^{38}$ Even in these early days, the bureau refused to limit itself to diet, going as far as handing out tips on doing laundry. ${ }^{39}$ From 1945 onwards, annual reports, board meetings and articles in Voeding all demonstrated the great sense of responsibility felt by bureau employees. The prevailing belief was that the bureau could and should play a significant role in correcting the lifestyle habits of the Dutch population. The organisation grew in size to accommodate these expansive goals. Its government subsidy rose from 125,000 guilders in 1942 to around 900,000 in 1965, facilitating an increase in staff levels from 17 to 41 employees. ${ }^{40}$

With its turn towards addressing overeating in the late 1940s, the bureau again showed its high ambitions. In its attempts to curtail weight gain and cardiovascular disease, the organisation did not restrict itself to nutrition education, but took on the much broader goal of lifestyle reform. Specifically, physical exercise was a constant concern. From 1947 onwards, publications focused on the diet of athletes and 'nutrition in sport' ${ }^{41}$ The 1958 leaflet on weight loss, From overweight to good weight, already made mention of sport as a sensible part of a weight loss regime. Physical exercise - burning calories - was becoming part of the conventional wisdom in the fight against overeating. In the same year, in a meeting of the board, chairman Dols pointed out that a campaign on overeating should pay 'great attention to the absolute necessity of sport and games'..$^{42}$ A year later, the bureau's first film with a soundtrack, titled The family portrait (Het familieportret), showed an average Dutch family that had gained weight because of 'an excessive diet and too little physical exercise'. ${ }^{43}$

After an international surge in the interest in sport nutrition during the early 1960 s $^{44}$, physical exercise became an even more urgent theme in

Biltekoff, Eating Right, 115. Biltekoff cites David Mark Hegsted, 'Recollections of Pioneers in Nutrition: Fifty Years in Nutrition', Journal of the College of Nutrition 9:4 (1990) 280-287, 284. DOI: https://doi. org/10.1080/07315724.1990.10720381. 'Enkele gedachten over voedingsvoorlichting', Voeding 6:7 (1946) 208-214, 213.

'Yearly DNEB report 1943', VMBV (1944) 399-414, 407. In 1965 , the bureau's budget was supplemented by 15: Board meeting of 1 June 1966. about 10 per cent income from sales. NA, 2.11.96, inv. 1947; 17 July 1947, 16 October 1947; 20 November 1947; 2 January 1948 (six-part series).

For example: De zwemkroniek, 20 March 1947; 1 May NA, 2.11.96, inv. 12: Board meeting of 8 December 1958. 'Yearly DNEB Report 1959', vMBV (1960) 1167-1213, 1176. Jon Verriet, "'Strong as a Bear, Gracious as a Gazelle": The Expansion of Female Athleticism in Dutch Sports Magazines and Advertisements for Sports Food and Beverages, 1960-1980', Marjet Derks (ed.), Yearbook of Women's History 38: Building Bodies. Gendered Sport and Transnational Movements (Hilversum 2019) 137-152, 142. 
the bureau's publications and lectures. ${ }^{45}$ Monitoring one's physical fitness was no longer just for professional athletes. Diet and exercise were presented as the two factors of greatest importance to healthy living - a mantra that became commonplace in the $1960{ }^{46}$ The focus on exercise dovetailed with the bureau's shift towards children as a key audience. Several publications aimed directly at children played into the idea that one of their great desires was to be 'fit'. As one leaflet put it: 'you want to be not just big, but strong, one of the best at gymnastics'. ${ }^{47}$ It should be clear then, that as early as the years immediately after the war, the bureau - despite its name - was working to effectuate not just dietary changes, but broad adjustments in individuals' way of living.

The bureau's relationship with the food industry and the ministries

Before expanding on the Dutch Nutrition Education Bureau's relationship with its target audience, I want to establish the way its staff perceived and managed their relationship with the food industry and a changing group of officials at two ministries. In the eyes of educators, these two crucial parties significantly affected their room for manoeuvre in trying to alter the lifestyles of the Dutch population. Over time, the bureau revised its stance towards both as it discovered the possibility (or impossibility) of cooperation with industry and government officials.

The bureau's initial attitude towards the food industry was one of trust. Before its foundation in 1941, cooperation between for-profit and non-profit food advisors had been common. ${ }^{48}$ Accordingly, when Voeding was founded in 1939, industry representatives obtained seats on its board. The bureau took a similar approach: it felt that advertisers could and should be partners in bringing about sensible food habits for the Dutch public. ${ }^{49}$ According to that logic, it made sense to grant companies the opportunity of sponsoring the 'Wheel of Five' ('de Schijf van Vijf, a diagram depicting the five 'food groups' that comprised the ideal diet). As part of the deal, their product would feature more prominently on the wheel..$^{50}$ In some areas, the bureau sport', Geneeskundige Gids 42 (1964) 1-5; Jan F. de Wijn, De voeding bij sportbeoefening. Richtlijnen voor kaderinstructie (The Hague 1965). Elseviers Weekblad 22:3 (1966) 11; 'Yearly DNEB Report 1967', Voeding $29: 7$ (1968) 307-348, 307-308.
48 Van Otterloo, 'Prelude op de consumptiemaatschappij', 269.

49 Den Hartog and Van Schaik, 'Enkele gedachten', 208.

50 G.I. ter Haar, G.P.J.M. de Bekker and J. Hammink, 'De Schijf van Vijf - een ideaal voedingsvoorlichtingsinstrument?', Voeding 40:2 (1979) $34-41,38$. 
had an even closer relationship with the food industry: its fish department was partly sponsored by the fishing industry.

By the beginning of the 1960s, the rapidly expanding food industry appeared to be getting a firmer hold on popular nutrition discourse in the Netherlands. Food advertisements were ubiquitous, with about a third of them containing a health claim..$^{51}$ However, most large companies went far beyond advertising, using sophisticated marketing methods in an attempt to forge an 'emotional' connection between consumers and their products. ${ }^{52}$ One example is Unilever, which had invested heavily in the development and popularisation of new products, instituting a sixfold increase in their R\&D budget over a period of just thirteen years. ${ }^{53}$

It appears that the bureau observed these developments with growing apprehension, as it slowly came to see the interests of corporations as fundamentally different from its own. Unsure about the validity of commercial nutrition education, director Den Hartog openly expressed the concern that consumers were being 'bombarded' with health claims. ${ }^{54}$ Accordingly, the bureau ended its collaboration with the fishing industry in 1964, after members of the board had repeatedly voiced doubts about the effect of this partnership on the bureau's objective image. ${ }^{55}$ By 1965 , that 1961 and 1975: G.J. Bos et al., '85 jaar voedingsmiddelenadvertenties in Nederlandse tijdschriften', in: Annemarie de Knecht-van Eekelen and Marianne Stasse-Wolthuis (eds.), Voeding in onze samenleving in cultuurhistorisch perspectief (Alphen aan den Rijn/Brussels 1987) 135-160, 150.
2008) 396-419, 399. DOI: https://doi.org/10.1093/ oxfordhb/9780199263684.003.0017.

H. van Otterloo, 'Naar variatie en gemak 1960-199o', in: Johan W. Schot et al. (eds.), Techniek in Nederland in de twintigste eeuw III: Landbouw, voeding (Zutphen 2003) 280-295, 287.

54 Cornelis den Hartog and Alice Copping, 'The Nutritional State of Europe and the Need for Education and Training in Nutrition', Voeding 21:2 (1960) 53-62, 58. 20 January 1947; 'Yearly DNEB Report 1963', VMBV (1964) 1361-1409, 1362. Educators had little room for manoeuvre: the Swedish colleagues of the bureau would later demonstrate that extensive collaboration with the food industry could do serious damage to their perceived impartiality. Fredrik Norén, "“6 to 8 Slices of Bread”: Swedish Health Information Campaigns in the 1970s', Scandinavian Journal of History 43:2 (2018) 233-259, 250. DOI: https://doi.org/10.1080/03468755.2018.143 0567. 
same board was deliberating the need for 'counter measures' (tegenacties) to correct the messages from food manufacturers. ${ }^{56}$ Though some members expressed doubts about the use of a more combative tone, a television spot taking aim at biscuits (koeken), marketed towards children, followed in 1968. Firmly warning against these sugary products, the spot formed one of the bureau's first public, explicit counter messages. ${ }^{57} \mathrm{~A}$ few years later, the annual report of 1972 echoed this change in approach. It castigated the industry, stating that many commercials contained 'highly questionable information' that at times could form a 'threat to public health'. At the same time, the report pointed out the shifting power dynamic, explaining that the bureau had only very limited opportunities to fight this giant. ${ }^{58}$

Ministry officials were the intended audience for these subtle complaints about the bureau's modest means. Though it did not make a habit of openly criticising its funding, allusions to the bureau's disappointing financial opportunities had been an occasional part of annual reports, the topic of many board meetings and the subject of several letters to its two sponsors, the Ministry of Social Affairs and Public Health and the Ministry of Agriculture, Fishery and Food Supply. ${ }^{59}$ The bureau intended to signal to policymakers that its financial situation limited its opportunities: the frugal salary budget established by the ministries, it claimed, had a direct effect on the quality of nutrition education in the Netherlands.

Bureau staff may have been aware that a more general lack of interest in public health existed in the political sphere. ${ }^{60}$ Overeating, the organisation's main concern from the 1950 os onwards, was hardly ever mentioned in the chambers of parliament. ${ }^{61}$ As late as the 1970 , even the more general topic of nutrition was rarely featured in the programmes of political parties. ${ }^{62}$ This, in part, explains the fact that the archives of the 1965 . the ministries' names had been changed to Public Health and Environmental Hygiene, and Agriculture and Fishery. 'Yearly DNEB Report 1947', VMBV (1948) 805-826, 805; Cornelis den Hartog, 'Gedachten bij het 12 1/2-jarig bestaan van het Voorlichtingsbureau van de Voedingsraad', Voeding 14:9 (1953) 410-415, 413; 'Yearly DNEB Report 1971', Voeding 34:3 (1973) 121-169, 125; Letters: NA, 2.11.96, inv. 12: Board meeting of 25 March 1957; inv. 14:

Board meeting of 13 April 1964; inv. 18: Board meeting of 3 September 1970.

60 Henk Rigter and René Rigter, 'Volksgezondheid: Een assepoester in de Nederlandse politiek. Een analyse toegespitst op de sociaal-democratie', Gewina 16:1 (1993) 1-17, 1.

61 Roel Pieterman, Gewicht zit niet tussen je oren: Beleid en wetenschap in perspectief (Amsterdam 2017) 54-55.

62 Annemarie de Knecht-van Eekelen and Anneke H. van Otterloo, 'What the Body Needs: Developments in Medical Advice, Nutritional Science and Industrial Production in the Twentieth Century', in: Alexander Fenton (ed.), Order and Disorder: The Health Implications of Eating and Drinking in the Nineteenth and Twentieth Centuries (East Linton 2000) 112-144, 129-130. 
bureau contain little information concerning interactions with politicians or with the ministries - although some meetings, of course, were 'off the record'.

Criticising politicians or officials at the ministries for a lack of interest required a delicate touch on the part of the bureau. In 1956, the organisation had deliberately been classified as a foundation (stichting) to prevent the appearance of propaganda. ${ }^{63}$ This meant that according to its statutes, the bureau could operate without any ministerial interference. At the same time, however, the foundation was almost entirely dependent on the ministries for its funding. As Den Hartog himself warned, this financial dependence meant the government could 'exert great influence on the bureau'. ${ }^{64}$ In the end, the general lack of ministerial interest gave the bureau significant room to set its own agenda, but when the ministries did speak up, it was inclined to listen. Hence, the strategies of the ministries as well as those of the food industry were seen as crucial by the bureau, which claimed that both parties limited its efficacy in reaching the target audience.

\section{Conceptualising and approaching the target audience}

Carefully positioning itself with respect to the ministries and to commercial parties, the Dutch Nutrition Education Bureau set out to reach its target audience to the best of its ability. In the decades after the Second World War this complicated relationship hinged, in part, on the bureau's approach of its audience and had significant consequences for the ambitions of its staff.

Though this article focuses on the direct relationship between the bureau and its target audience, it should be noted that the organisation also tried to forge an indirect relationship with the Dutch population through what it called its cadre (kader) - intermediaries such as external health professionals, school teachers, the media and consumer organisations. The bureau's collaborations with this cadre, however, were marked by increasing frustration. Some organisations proved ideal partners in the quest for healthy living, such as the Consumers' Union, which consulted the bureau before publishing anything food-related ${ }^{65}$, and the Dutch Heart Foundation, which found a willing partner in the bureau for its promotion of dietary moderation and physical exercise. However, the annual reports, articles in Voeding, and the minutes of meetings suggest little success was achieved with two vital groups: health professionals and school teachers. Den Hartog wrote in 539. In West Germany, colleagues in the Deutsche Gesellschaft für Ernährung also set up their organisation on a non-profit basis, because the perceived legitimacy of government information was a problem post-World War II. Thoms, 'Learning from America?', 143.

64 NA, 2.11.96, inv. 23: Board meeting of 30 September 1975 .

65 'Yearly DNEB Report 1963', vMBV (1964) 1361-1409, 1387. 
frustration in 1964 that teachers were 'generally ignorant of even the simplest principles of nutrition' ${ }^{66}$ Doctors were hardly any better, according to an annual report, which called them 'completely unaware of the importance of food for health' ${ }^{67}$ Year in and year out, the bureau was unable to reach these professionals, either with its promotional material or through Voeding, which, despite various efforts, neither group read. ${ }^{68}$ This might explain why the bureau, after shifting some of its focus to intermediaries around 1955, had opted for a re-intensification of direct communications with the general population by $1970 .^{69}$

Such direct interaction between the bureau and the public was more immediately gratifying. Frequent contact was also necessary to be able to adequately conceptualise audiences in order to optimise the organisation's messages. Even before the foundation of the bureau, educators had segmented their audience and differentiated their instructions. A 1940 guideline on nutrition education, for instance, contended that it was time to look beyond the housewife. ${ }^{70}$ Other articles stressed the difference between the city and the countryside, noting that messages should be 'as individualised as possible'.71 It should be noted that much of the bureau's material still addressed women. Not only because of gendered language or the use of certain imagery, but also because meal preparation was a thoroughly gendered practice in the post-war Netherlands. ${ }^{72}$ As a consequence, despite the bureau's intentions, it was predominantly middle-class housewives who tended to show up for its lectures and buy its leaflets.

Reaching all segments of society proved difficult for the bureau. Its strenuous attempts to communicate with what it termed the 'most vulnerable groups' are illustrative. ${ }^{73}$ The bureau's own research indicated that income and education levels correlated with both knowledge of and adherence to the bureau's lifestyle advice. ${ }^{74}$ When a 1954 leaflet aimed at factory workers was criticised during a board meeting, one staff member confessed that 'it had been difficult to get a sense of the interests of factory workers' ${ }^{75}$ Moreover, the bureau received feedback suggesting that its leaflets contained language

Netherlands', Voeding 25:3 (1964) 179-184, 182.

Cornelis den Hartog, 'Nutrition Education in the

'Yearly DNEB Report 1973', Voeding 36:1 (1975) 1-39, 1.

NA, 2.11.88, inv. 422: Rapport 'Persberichten. Meningen-wensen-toepassing: enquête' (1969) 6.

'Yearly DNEB Report 1955', vMBV (1956) 481-536, 481; 'Yearly DNEB Report 1970', Voeding 32:10 (1971) 510-547, 512

E.G. van 't Hoog and G.P.J. van Overbeek, 'Practische voorlichting op voedingsgebied', Voeding 2:4 (1940) 144-156, 146.
Cornelis den Hartog and Theodora van Schaik, 'Beschouwing over de gebruikelijke methodiek bij de voedingsvoorlichting I', Voeding 9:5 (1948) 200204, 200. 348, 315; 'Yearly DNEB Report 1968', vMBV (1969) 1-54, 19; 'Yearly DNEB Report 1970', Voeding 32:10 (1971) $510-547,522$.

Verriet, 'Ready Meals', 132-134.

'Yearly DNEB Report 1951', vMBV (1952) 537-575, 537. 'Yearly DNEB Report 1967', Voeding $29: 7$ (1968) 307A, 2.11.96, inv. 29: Advisory Board meeting of 29 
that was too complicated for some. ${ }^{76}$ Suppressing personal proclivities in the production of new material appears to have been difficult for bureau staff. It is therefore no surprise that a small survey found the organisation's lifestyle advice was especially popular among its own personnel. ${ }^{77}$ Some measures were taken to acknowledge and overcome this middle-class bias. One example is that the bureau made efforts to keep its publications and lectures affordable. ${ }^{78}$ To facilitate communication with the 'socially lower classes' (sociaal lagere klassen) it had started early on to pre-test material using a council of housewives 'stemming from different groups of the population' ${ }^{79}$ It also relied on intermediaries for getting its message across in communities that were culturally or religiously dissimilar. ${ }^{80}$

The complex relationship the bureau had with sections of its audience was nevertheless still apparent at times. Despite its efforts at accommodating people who were having trouble following the bureau's recommendations, Den Hartog also appeared to resent their lifestyle choices. In 'culturally backward areas', he wrote in Voeding in 1961, he found people 'tenaciously clinging to certain food habits'. In these cases, he believed, 'culture' was mostly an obstacle:

Though at first sight nutrition may seem to be exclusively a matter of biology, the nutritional adviser soon learns that culture is of great importance in human nutrition. The adviser is continually confronted with the fact that, owing to the established values, standards, purposes and expectations of the group, the scientifically founded nutritional advice is disregarded. ${ }^{81}$

Internal reports that remarked upon audiences' presumed preference for televisions, Solexes (light motorbikes) and inbreeding (inteelt) seem to confirm feelings of superiority among the educators. ${ }^{82}$ Consequently, some audiences might have felt alienated from bureau employees, both because of class differences and the palpable condescension of educators. Hence, similar to communications with intermediaries, direct interaction with the public was a continuing challenge for the bureau throughout the period from 1941 to 1980.

\section{The efficacy and the revision of methods}

Despite the cultural differences between its staff and sections of its audience, the late 1940 and most of the 1950 os formed a markedly optimistic era for the in the Netherlands', Voeding 22:1 (1961) 35-40, 36.

81 Den Hartog, 'Culture and Nutritional Advice in the Netherlands', 39, 35 .

82 NA, 2.11.96, inv. 30: Advisory Board meeting of 4 February 1957. 
Dutch Nutrition Education Bureau. Though the future would bring signs of the bureau's disappointing societal impact, annual reports of these early years anticipated favourable conditions for the profession of nutrition education. With the dominance of the food industry over representations of healthy living still far from absolute, the bureau's report of 1954 claimed that people were increasingly seeing the value of nutrition education, and that they were turning towards the bureau in growing numbers. ${ }^{83}$ Lacking scientific indications of its actual impact, the bureau often took its considerable output as proof that it was changing lives (see Table 1). The growing number of people who knew about the Wheel of Five was taken as another manifestation of the bureau's influence, though the wheel's actual ability to affect lifestyles was not measured. ${ }^{84}$ The fact that people's familiarity with the bureau's message was in no way a guarantee of a broad change in everyday habits was ignored: the yearly report from 1955 concluded that inadequate dietary practices were 'generally' the result of ignorance. ${ }^{85}$

$\begin{array}{ll}\text { Printed material (sold) } & 560,605 \\ \text { Individual dietary advise } & 6816 \\ \text { Lectures (often incl. a film produced by the bureau) } & 222 \\ \text { Press releases } & 38 \\ \text { Booths at public exhibitions } & 24\end{array}$

Table 1. Yearly output, on average, of the Dutch Nutrition Education Bureau, 1945-1969 (printed material, individual dietary advise) and 1945-1980 (lectures, press releases, booths). This table is compiled by the author based on the annual reports published in Verslagen en Mededelingen betreffende de Volksgezondheid $(1945-1966,1968)$ and Voeding (1967, 1969-1976, 1978-1980) and Nationaal Archief, Stichting Voorlichtingsbureau voor de Voeding en taakvoorgangers en de Stuurgroep Project Goede Voeding (1987-1998), 2.11.88, inv. 65: 'Yearly DNEB Report 1977'.

The bureau tried to keep up with the latest innovations in education methods. Though there was no system of large-scale, structural feedback in place, bureau employees nonetheless reflected on their performance. Time and again, American discoveries were influential, especially in 1951, when Den Hartog completed a three-month visit to the United States along with many other European colleagues as part of the European Recovery Program, while head of education Theodora van Schaik (1915-1988) (Figure 3) acquired a master's degree in Food and Nutrition at the agricultural university of East Lansing in Michigan. ${ }^{86}$ Two of the bureau's most important representatives,

83 'Yearly DNEB Report 1954', VMBV (1955) 487-540, 487.

84 Ter Haar, De Bekker and Hammink, 'De Schijf', 38. By 1976, 26 per cent of the Dutch population had at least heard of the Wheel of Five, and 51 per cent recognised it on sight.

85 'Yearly dNEB Report 1955', vMBV (1956) 481-536, 481-482.
86 Adel P. den Hartog, 'The Diffusion of Nutritional Knowledge: Public Health, the Food Industry and Scientific Evidence in the Netherlands in the Nineteenth and Twentieth Centuries', in: Derek J. Oddy and Lydia Petráňová (eds.), The Diffusion of Food Culture in Europe from the Late Eighteenth Century to the Present Day (Prague 2005) 282-294, 286; Thoms, 'Learning from America?', 117, 120. 


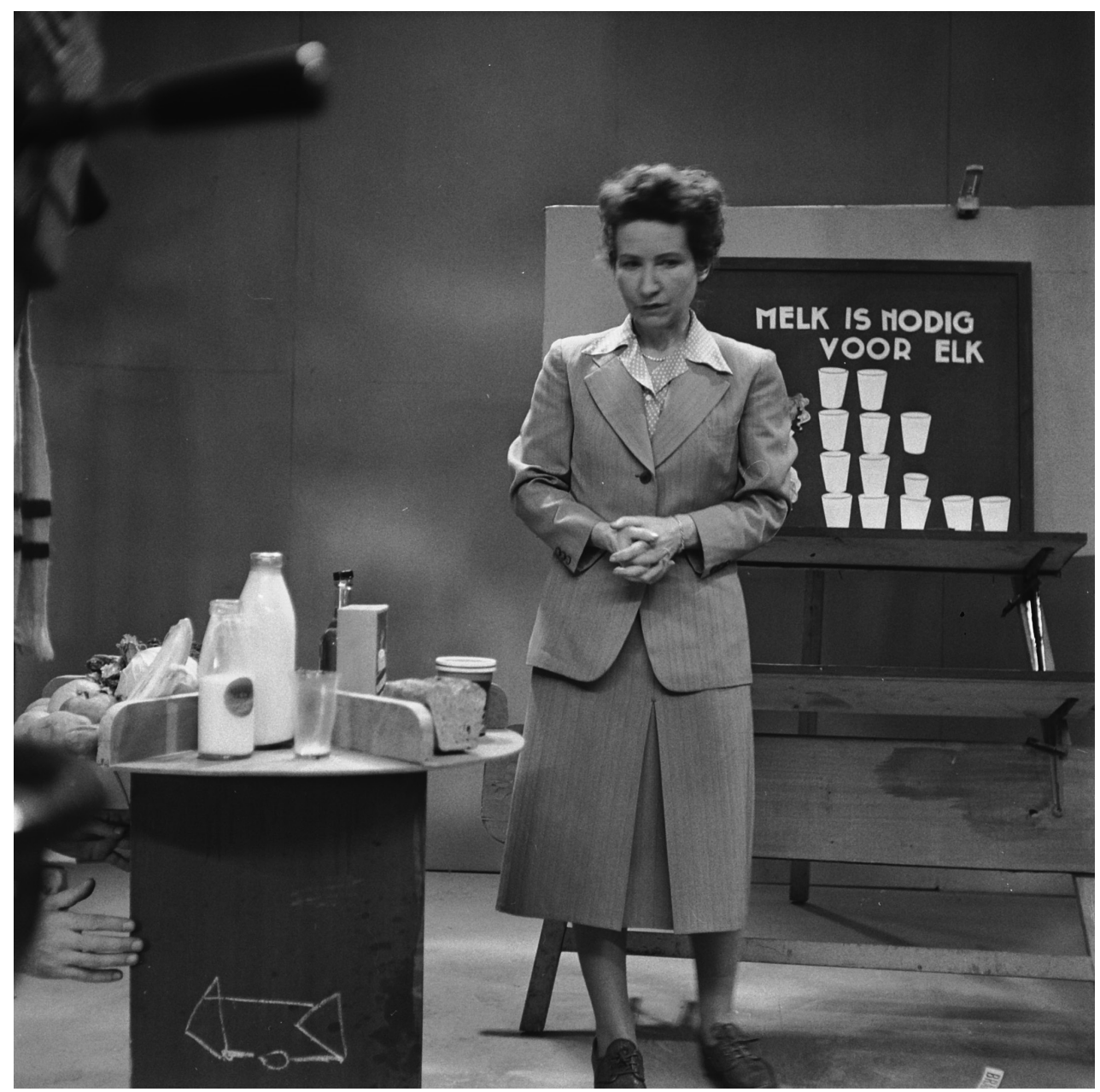

$\Delta$

Figure 3. Theodora van Schaik (1915-1988), a crucial figure in the early decades of the Dutch Nutrition Education Bureau, first as head of education (1941-1964), then as head of general nutrition affairs and nutrition research (1965-1970). Here, Van Schaik educates the viewers of the Dutch 1953 TV show Onder nul (Below zero) on what to eat and drink in wintertime. Photograph taken on 29 December 1953. ( ANP. 
Den Hartog and Van Schaik, made sure that 1952 would become 'the birth year of new starting points, new channels, new methods and new resources ${ }^{87}$, with the organisation shifting its focus towards the visualisation of material and the self-motivation (zelfwerkzaamheid) of audiences. ${ }^{88}$ With the financial help of the us's Mutual Security Agency, which sought to turn Europeans into responsible consumers, nutrition education became more interactive. Press material started to include more illustrations and lectures became 'an exchange of ideas', often featuring a film. ${ }^{89}$ In 1953 , the bureau hired an expert in 'press, propaganda and aesthetic advice', and eventually its staff became determined to make an impact through both radio and television as well.

International contacts were essential to the development of the bureau's output. Many foreign organisations sent material to their Dutch colleagues, who took a keen interest. Yearly reports also boasted membership of organisations such as the American Dietetic Association, the Council of the British Nutrition Society and the Deutsche Gesellschaft für Ernährung, together with many visits to conferences, such as the French Journées Nationales de Diététique, the International Dieticians Congress and the Group of European Nutritionists Congress. Apart from exchanging information with Us nutritionists and officials (between 1945 and 1980, 89 per cent of yearly reports mentioned contact with Americans), the bureau primarily focused on European colleagues. Nevertheless, its network stretched far, as shown by mentions of contact with educators from Argentina, Ghana, Iran and Thailand.

Though fellow educators, particularly those from the us, had a notable impact on the strategies used in the Netherlands, the bureau also boasted of its own impact on the world. Substantial interest in the bureau's publications existed in West Germany, where nutrition education material was 'generally unreadable' in the 1950 s, according to historian Ulrike Thoms. ${ }^{\circ}$ However, French, English and Belgian educators also showed interest, because of the bureau's succinct, modern writing and its extensive use of visuals ${ }^{91}$, and many 'fellows' from all over the world visited the bureau for weeks at a time. For bureau staff, going abroad was not always a learning experience, but at times also a reminder that the bureau could be an 'example' to foreign colleagues and that its publications were 'among the best'. ${ }^{92}$ The years between 1945 and 1960 in particular comprised a period of optimism, with the yearly report of 1959 concluding that education techniques were becoming 'ever more perfect'. ${ }^{93}$

'Yearly DNEB Report 1952', VMBV (1953) 57-97, 57.

'Yearly DNEB Report 1951', VMBV (1952) 537-575, 539;

'Yearly DNEB Report 1954', VMBV (1955) 487-540, 487.

'Yearly DNEB Report 1952', vMBV (1953) 57-97, 77-78;

Thoms, 'Learning from America?', 119.

'Yearly DNEB Report 1948', vMBV (1949) 433-457, 449;

Thoms, 'Learning from America?' 145.
91 'Yearly DNEB Report 1953', VMBV (1954) 569-617, 596; 'Yearly DNEB Report 1954', VMBV (1955) 487-540, 496.

92 NA, 2.11.96, inv. 17: Board meeting of 24 April 1969; inv. 34: Advisory Board meeting of 25 February 1970.

93 'Yearly DNEB Report 1959', vMBV (1960) 1167-1213, 1167. 
At the same time, there was an awareness that only a better understanding of the behaviour of the Dutch public would lead to optimally designed communications. Ultimately, increased insight into nutrition education's disappointing effects on actual behaviour would lead to a thorough re-evaluation of the bureau's approach and an adjustment in strategy in the mid-1970s. However, initial calls for the application of insights from social psychology to comprehend how people made lifestyle decisions and the polling of audiences did not stem from worries about efficacy. In fact, the application of the social sciences in governance to help understand audiences was part of an international optimism about social engineering, or the 'scientisation' of (governmental) policy. ${ }^{94}$ For years, the bureau appealed for the employment of sociological and/or psychological knowledge in yearly reports and in articles in Voeding as well as in informal conversations with the ministries, which had a substantive say in staffing policies. Eventually, in 1965, the bureau was allowed to appoint one social psychologist, Leonarda Klinkert. ${ }^{95}$ Tasked with reviewing the efficacy of nutrition education in the Netherlands, she quickly indicated that measuring the bureau's impact would demand more staff and a bigger budget. But despite many calls for more research on this matter, financial possibilities stayed limited and results remained meagre. ${ }^{96}$

Despite difficulties in measuring the bureau's impact, there had been early signs that called for some scepticism. The 1953 yearly report commented on discrepancies between the public's knowledge and their lifestyle choices: though go per cent of a lecture's audience knew that brown bread was 'the best bread' and while 'everyone' was aware that they were supposed to drink three-quarters of a litre of milk per day, the educator had found that actual practices deviated greatly from these standards. ${ }^{97}$ Around the same time, one bewildered advisory board member asked a simple question, foreshadowing things to come: 'why don't people do as they're told?'98 By the early 1960 , the rapidly increasing consumption of fats and sugar - the two things the bureau rallied against - seemed to indicate that the bureau's output was having little effect on actual lifestyle choices. Social Sciences in Western Societies, 1880-1980: Reflections on Trends and Methods of Current Research', in: Kerstin Brückweh et al. (eds.), Engineering Society: The Role of the Human and Social Sciences in Modern Societies, 1880-1980 (Basingstoke/ New York 2012) 41-56, 52-53. DOI: https://doi. org/10.1057/9781137284501_2.
'Yearly DNEB Report 1964', VMBV (1965) 1569-1621, 1570.

96 For example, in 1948 and 1973: Cornelis den Hartog and Theodora van Schaik, 'Beschouwing over', 204; 'Yearly DNEB Report 1973', Voeding 36:1 (1975) 1-39, 2.

97 'Yearly DNEB Report 1953', VMBV (1954) 569-617, 602-603.

98 NA, 2.11.96, inv. 29: Advisory Board meeting of 12 May 1952. 
In the 196os, using small-scale surveys, social psychologists increasingly confirmed that nutrition education was having a disappointing impact. A 1965 article in Voeding by Mathilda Jansen was representative of the shifting mood. In this piece, titled 'Changes in behavioural patterns in the case of nutrition education, seen through the eyes of the social psychologist', she warned that she was curious about:

[w] hether people genuinely think that the food habits of people can be changed just like that. As a psychologist, this seems far from self-evident to me. A person changes their behaviour sporadically, and even then, very slowly. ${ }^{99}$

Surveys substantiated this conviction. A 1947 study from the us, cited in Voeding in 1957, found that the effect of nutrition lectures on audiences' food habits was discouraging. ${ }^{100}$ It confirmed that the lack of impact was an international problem: in countries like the us and West Germany, most people were listening 'to a sermon of moderation while eating away to excess'. ${ }^{101}$ In 1967 , Dutch research produced similar results: housewives with greater knowledge of nutrition did not serve 'healthier' meals than their peers (see Figure 4). Efforts to critically examine the bureau's efficacy increased. By 1972, 'evaluation research' had become a separate section in the yearly reports and the bureau had become a member of the Education Study Group, the Contact Centre for Education and the Foundation for Health Information and Education. ${ }^{102}$

Despite the bureau's department heads increasing aspiration to have an interactive 'exchanges of ideas' with audiences, educators in the field were hesitant. Not only did educators fail to lower the level of abstraction in these 'chats ${ }^{9103}$, they also kept telling audiences to remain quiet. ${ }^{104}$ The clash between the forward-thinking leadership and these reticent employees continued into the 1970s, as Heleen Rijneveld-van Dijk, the then head of eetgedrag van mensen zo maar gewijzigd kan worden. Als psycholoog lijkt me dat namelijk helemaal niet zo vanzelfsprekend. De mens wijzigt zijn gedrag slechts sporadisch en dan nog zeer traag'. Translation by author. Mathilda Jansen, 'Wijziging in het gedragspatroon bij voedingsvoorlichting, bezien door de sociaalpsycholoog', Voeding 26:4 (1965) 138-146, 138.

100 Pieter B. Ornee, 'Onderzoek naar de resultaten van menuverbetering door voorlichting of extra melkvoeding bij schoolkinderen', Voeding 18:1 (1957) 29-105, 99-100. Ornee cites Kurt Lewin, 'Group Decision and Social Change', in: Theodore
Newcomb and Eugene Hartley (eds.), Readings in Social Psychology (New York 1947) 197-211.

101 Thoms, 'Learning from America?', 149; Quote from DuPuis, 'Angels and Vegetables', 34.

102 'Studiekring Voorlichting', 'Het Contactcentrum op Voorlichtingsgebied', 'De Stichting Gezondheidsvoorlichting en -opvoeding'. 'Yearly DNEB Report 1972', Voeding 35:2 (1974) 100-167, 164.

103 Cornelis den Hartog and Theodora van Schaik, 'Een nieuwe wijze van voedingsvoorlichting', Voeding 14:5 (1953) 251-252.

104 'Yearly dNEB Report 1951', vMBV (1952) 537-575, 561-562; 'Yearly DNEB Report 1952', VMBV (1953) 57-97, 59 . 


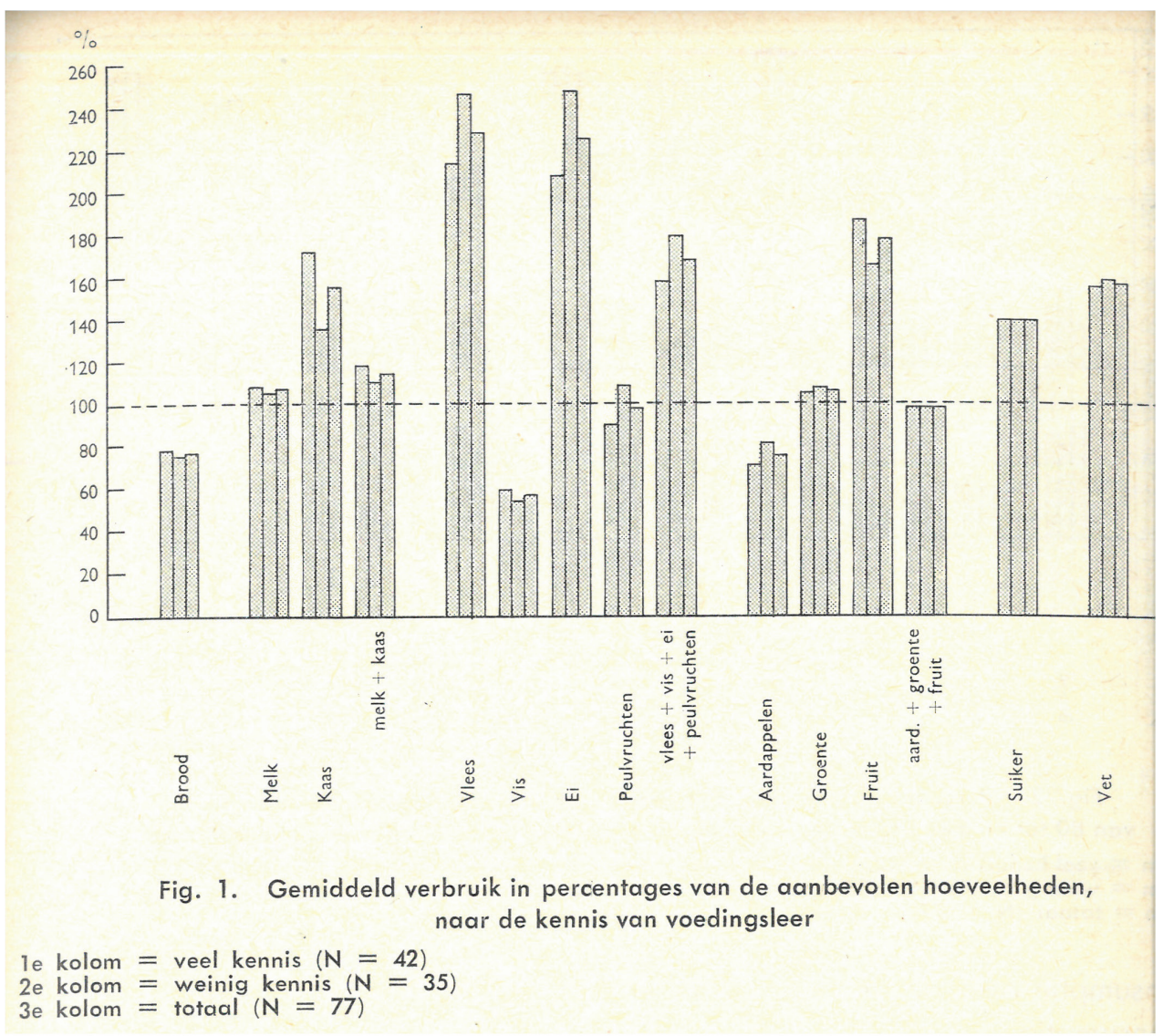

Figure 4. This graphic shows the results from a study on the relationship between people's nutrition knowledge and their food habits. Based on a survey conducted among 77 Dutch housewives, the study concluded that among these women, familiarity with basic nutrition science had no significant effect on the use of different types of ingredients. Taken from: Meintje Peters-Nanninga and Hadewijch Bessems-Destaebele, 'De invloed van de kennis van voedingsleer op de voeding van het gezin', Voeding 28:3 (1967) 103-111, 105. (C) Meintje Peters-Nanninga and Hadewijch Bessems-Destaebele. 
the department of audio-visual communication, didactics, public relations, design and production of material, explained in a series of articles in Voeding. She raised the concern that certain educators still preferred the outdated leaflet format, and that some persisted in a 'just do as I say' attitude. ${ }^{105}$

More structural issues lay at the core of the troubles with personnel. According to Van Schaik, bureau staff were overworked under Den Hartog, a 'charming dictator' who worked day and night. ${ }^{106}$ Apart from Den Hartog's demanding approach, staff were also feeling the effect of significant employee turnover: almost half of the bureau's female employees stayed for a maximum of two years. As these young dieticians generally left working life to get married, as was the norm during these decades, it caused a severe lack of continuity. ${ }^{107}$ What also did not help was the existing salary cap -a source of constant negotiation with ministry officials - that made filling vacancies very difficult. ${ }^{108}$ The most challenging vacancy to fill, however, turned out to be that of Den Hartog. After he became full professor in 1969, the bureau had three directors in just three years before settling on a more permanent candidate. By then, an internal report concluded, the bureau was underperforming, in part because without their 'charming dictator', departments were becoming more and more autonomous. ${ }^{109}$

By the mid-1970s, the lack of effect generated by 35 years of nutrition education had become deeply disappointing to employees of the bureau. Despite efforts in the Netherlands and abroad to curtail the 'nutrition transition', global fat and sugar consumption kept rising throughout the 1960 and $1970{ }^{110}$ in correlation with obesity levels. ${ }^{111}$ In many countries, the optimism about the possibilities of social engineering had started to dwindle. ${ }^{112}$ As a result, the bureau's yearly report of 1977 was characterised by a substantial shift in tone. Opening with a broad contemplation of

105 Heleen Rijneveld-van Dijk, 'Hoe zeg ik het de ander?' Voeding 34:3 (1973) 117-120, 118; Heleen Rijneveld-van Dijk, 'Hoe zeg ik het de ander? II', Voeding 35:3 (1974) 190-194, 190.

106 Van Schaik, 'Professor Dr.', 544; Bosman, 'In memoriam', 5 .

10743 per cent between 1942 and 1960. Up to 1957, Dutch law prohibited married women from holding governmental positions. Cornelis den Hartog and Theodora van Schaik, 'Vijfentwintig jaar Voorlichtingsbureau voor de Voeding', Voeding 26:6 (1965) 398-419, 401.

108 NA, 2.11.96, inv. 12: Board meeting of 25 March 1957; inv. 14: Board meeting of 13 April 1964. 109 NA, 2.11.96, inv. 23: Board meeting of 24 April 1975.
110 Joint WHO/FAO Expert Consultation on Diet, Nutrition and the Prevention of Chronic Diseases, 'Diet, Nutrition and the Prevention of Chronic Diseases', wHO Technical Report Series 916 (Geneva 2003) 13-29.

111 It is difficult to find pre-1975 BMI statistics, but an increase starting (at least) in 1945 is likely. NCD Risk Factor Collaboration, 'Worldwide Trends in Body-Mass Index, Underweight, Overweight, and Obesity from 1975 to 2016: A Pooled Analysis of 2416 Population-based Measurement Studies in 128.9 Million Children, Adolescents, and Adults', The Lancet 390:10113 (2017) 2627-2642. DOI: https:// doi.org/10.1016/S0140-6736(17)32129-3.

112 Raphael, 'Embedding the Human', 53. 
transnational food habits, it concluded that while the nutritional knowledge of the Dutch population was adequate, its application left much to be desired. 'Should the Nutrition Education Bureau have prevented such an expansive “change” in the consumption pattern?' its authors asked, adding, '[w] ould it all have gone differently if we had educated in a different way?'113

\section{The strategic adjustment of the mid-1970s}

The Dutch Nutrition Education Bureau kept reviewing and altering its practices for a period of over thirty years, continually looking to improve its methods. By the mid-1970s, it concluded that overeating was a complex, multicausal problem which demanded broad lifestyle changes in matters such as diet, smoking, drinking, exercise, the release of stress, and sleep. ${ }^{114}$ At the same time, the post-war decades saw an ever more powerful food industry and a government with little apparent interest in health interventions. This explains the dejected tone of the 1977 annual report: with obesity levels rising quickly, the bureau's problems must have seemed insurmountable.

Under these circumstances, a healthist narrative on audiences' own responsibility, which had gained traction since the late 1950 , became pervasive. It had started with the annual report of 1958, suggesting that overeating was a problem for which 'our population will partly have to find the solution itself' ${ }^{115}$ In 1960, an article in Voeding co-written by Den Hartog, moralised dietary choices by emphasising the effect of bad eating habits on the rising cost of health care. ${ }^{116}$ There was an international political context for this stance. In the same year, us President John F. Kennedy had spoken of the 'softness' of the nation and appealed to Americans to return to 'physical vigour'. ${ }^{117}$ Furthermore, at the end of the 1960 , politicians in the Netherlands challenged the Dutch population in a similar way, bemoaning the spread of 'potbellies' because of bad food habits and 'weak muscles' due to lack of exercise. ${ }^{118}$ Consequently, many national governments started 'Sport for All' campaigns to revitalise the population. At the same time, with the rise of healthism, overeating was increasingly individualised. A thin and healthy

113 NA, 2.11.88, inv. 65: 'Yearly DNEB Report 1977', 3.

114 For example: NA, 2.11.88, inv. 295: 'Trim ook met je vork' (1974); inv. 122: 'Eet verstandig, eet matig' (1978) and Wayne Wilson (eds.), The Oxford

Handbook of Sports History (New York 2017)

29-44, 34. DOI: https://doi.org/10.1093/

oxfordhb/9780199858910.013.12.

118 Harm Kaal, 'A friendly match: sport and political

culture in the Netherlands between the 1950 and

the 1970s', in: Paul Puschmann and Tim Riswick

(eds.), Building Bridges. Scholars, History and

Historical Demography. A Festschrift in Honor of

Professor Theo Engelen (Nijmegen 2018) 216-236, 231. 
body was becoming both an individual moral goal and a duty towards others. Educators, conceivably because they were overwhelmed by the magnitude of their task, found merit in this way of thinking.

By the mid-1970s, the bureau decidedly changed course. The new strategy was called 'emancipation': people should be entirely free to dismiss well-meant advice. In 1975, it proudly presented a 'discussion film' titled You should decide for yourself(Je moet het zelf maar (w)eten), which was designed to create awareness among adolescent viewers to help them set their own dietary priorities. ${ }^{119}$ In the animation, people from various class backgrounds and with different body shapes describe their food habits (see Figure 5). ${ }^{120}$ Loosely based on a set of interviews, the film presents without comment what the bureau considered correct opinions, such as 'it is bad to eat without variation', alongside 'bad practices': 'I want [...] endless amounts of whipped cream, all day long'. After it was shown in a theatre, the bureau took a small survey among adolescents, revealing that the film was well-liked. ${ }^{121}$ Rijneveld-van Dijk, head of audio-visual communication, suggested that You should decide for yourself could be used in a broader context and that it had the ability to bring new inspiration to the profession of education in general. ${ }^{122}$ According to the 1976 yearly report, the production was a big hit at international film festivals, which was taken as proof that it was far ahead of its time. ${ }^{123}$ The film's relative success appeared to confirm that the healthist focus on 'emancipation' was the way forward.

It seems that for some educators, this adjustment in the relationship with their target audience did not stem from new-found, deeply held healthist convictions. Instead, it formed a practical answer to their experience of powerlessness. This conclusion is supported by the fact that several educators felt very conflicted about promoting 'responsibilisation' while overseeing an expanding cacophony of contradictory lifestyle advice. The bureau's 1978 yearly report concluded that it was making 'particularly heavy demands' on consumers' individual responsibility, in spite of their increasing confusion and insecurity. ${ }^{124}$ An author of a 1980 article in Voeding noted that while people certainly had agency, the relentless popularisation of all kinds of lifestyle instructions typical of 'late capitalist consumer society' demanded a lot from individuals. ${ }^{125}$ 669,629 .

Design, script and art direction by Harrie Geelen. Toonder Studio's BV.

The film was shown after the main feature. Heleen Rijneveld-van Dijk, 'Het tot stand komen van een

'Yearly DNEB Report 1975', Voeding 37:11 (1976) 629-

The film can be viewed at the Eye Filmmuseum. voorlichtingsfilm op voedingsgebied', Voeding 37:11 (1976) 620-625, 622, 623.

122 Rijneveld-van Dijk, 'Het tot stand komen', 622.

123 'Yearly DNEB Report 1976', Voeding 38:11 (1977) 594-641, 617.

124 'Yearly DNEB report 1978', Voeding 41:4 (1980) 1-17, 2.

125 Koen Blokker, 'Doelen van voedingsvoorlichting', Voeding 41:4 (1980) 135-138, 135. 

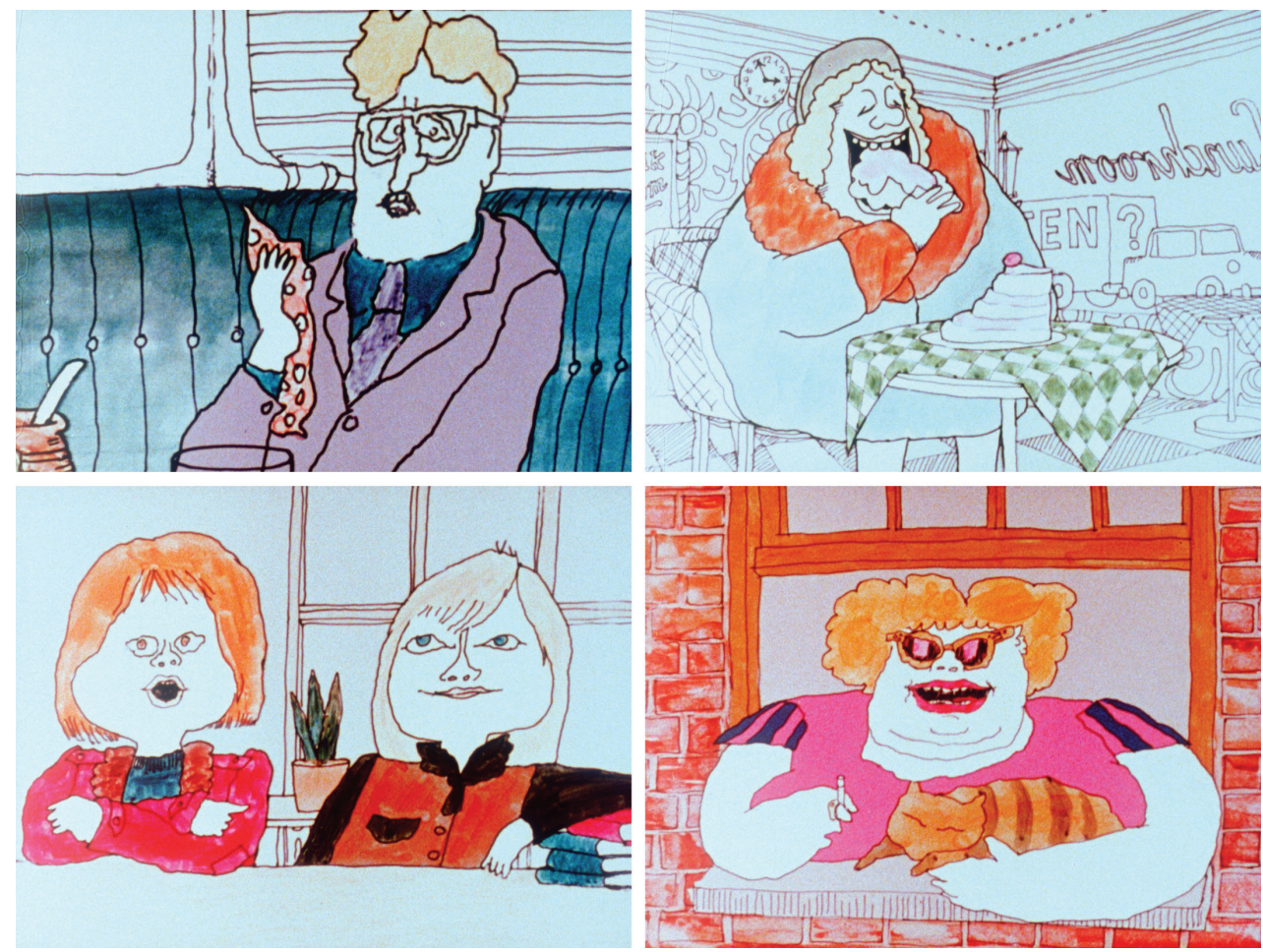

$\Delta$

Figure 5. Four stills from the film Je moet het zelf maar ( $w$ )eten (You should decide for yourself) from 1975, commissioned by the Dutch Nutrition Education Bureau. The film presented both 'good' and 'bad' food practices, as described by a diverse group of interviewees. Although it was intended to be non-judgmental, it did imply a direct relationship between people's body size and their dietary choices. (C) Toonder Studio's BV. Collection of the Eye Filmmuseum. 
There was another sign that the adherence to the logic of healthism might have been somewhat superficial. While their goal in the 1970 s was the 'emancipation' of the general population, bureau employees also increasingly called for direct government interventions, such as prohibiting the use of particular ingredients, levying import duties on certain products, making clear food labelling mandatory, and incorporating nutrition education into schools' official curricula. ${ }^{126}$ Hence, the bureau took an ambiguous position in the 1970s. Cognisant of the influence of powerful societal actors and of a public that was uncertain yet unresponsive, it was forced to re-evaluate its stance. The turn to the healthist narrative of 'emancipation' formed only a partial solution.

\section{Concluding remarks}

The post-war decades turned out to be an era of increasing frustration for the Dutch Nutrition Education Bureau. Not only did it find that its interests deviated more and more from those of the powerful food industry and the Dutch ministries, but it also strained to reach all audiences, struggling to get its message heard - and more importantly, implemented. Despite these difficulties, the bureau broadened its scope. Starting from the position that effectively changing people's lifestyles meant comprehensively changing people's lifestyles, it turned towards the issue of physical exercise and even to smoking, stress management and sleep. Eventually, to resolve the discrepancy between its expanding mission and its uncertain societal impact, it latched onto the healthist discourse of 'emancipation'. From the mid-1970s onwards, the bureau would inform the public, but individuals would keep full authority - and responsibility - over their own lifestyle decisions.

By centring the opinions and experiences of bureau staff, this article has highlighted the impact that health educators' evolving relationships with other actors had on the (re)formulation of their instructions. The significant struggles of the Dutch Nutrition Education Bureau preceding its change in strategy in the 1970s suggest that an analysis of educators' ideological shift to healthism cannot adequately be explained by their adherence to scientific consensus or ideas about 'good citizenship', but needs to take a long-term view at their experiences and practical considerations. Specifically, educators' reflections on the relationship with their target audience and the efficacy of their output help to understand the production process of lifestyle advice, shedding light on the historical development of the genre. On its most basic 
terms, therefore, this case study builds on the conclusion reached by others that in the post-war Netherlands the popularisation of neoliberal ways of thinking such as healthism could occur through other channels than political parties. ${ }^{127}$ More importantly, it supports the argument that historical research on broad, transnational changes in ways of thinking about public health should not lose sight of their concrete and practical context.

At first glance, the bureau's stance towards 'emancipated' individuals appears to have changed little since the end of the 1970s. A self-published book about the history of the organisation from 2014 opens with its director's reassurance that people are now free to make their own lifestyle choices. The time of judgmental educators and their 'finger wagging', he explains, is in the past. ${ }^{128}$ In the twenty-first century, many health professionals in the Netherlands and in other countries have demonstrated a continued focus on the healthy lifestyle and on the responsibility of the individual citizen - as much of the literature cited in this article's introduction attests to. This points towards avenues for future research, which could both connect and contrast current ideas about healthy living to the past, bridging the gap between the post-war decades and the present. Specifically, the history of promoting, negotiating and resisting the healthy lifestyle could be analysed through the interactions between a broad range of national and transnational actors, such as health professionals, NGOs, (sports) celebrities, health gurus, the food industry, government officials, and audiences, to increase our understanding of the complex developments that continue to shape popular ideas about public health.

\section{Jon Verriet is a PhD candidate at Radboud University Nijmegen, specialised in the twentieth-century history of food habits and physical exercise. His work examines the way in which popular ideas about health and other cultural values have affected people's 'lifestyle' choices. A key publication of his is: 'Ready Meals and Cultural Values in the Netherlands, 1950-1970', Food \& History 11:1 (2013) 123-153. DOI: https://doi.org/10.1484/ J.FOOD.1.103558. Verriet's PhD project is titled: Fitter, Stronger, Faster: The Pursuit of Healthy Lifestyles in the Netherlands and the U.S. (1945-2020). E-mail: J.Verriet@let.ru.nl.}

127 Bram Mellink, 'Politici zonder partij: Sociale zekerheid en de geboorte van het neoliberalisme in Nederland (1945-1958)', BMGN - Low Countries Historical Review 132:4 (2017) 25-52, 52. DOI: https:// doi.org/10.18352/bmgn-lchr.10220.
128 After a merger, the name of the bureau was changed to Nutrition Centre (Voedingscentrum) in 2000. Quote from director Felix Cohen. Truska Bast and Boudewijn Breedveld, Van schaarste naar overvloed: 70 jaar voedingsvoorlichting in Nederland (The Hague 2014) 5. 